\title{
Effects of Cow Diet on the Microbial Community and Organic Matter and Nitrogen Content of Feces
}

\author{
P. C. J. van Vliet, ${ }^{\star}$ J. W. Reijs,† J. Bloem,‡ J. Dijkstra,§ and R. G. M. de Goede* \\ *Department of Soil Quality, \\ †Department of Animal Sciences, \\ $\ddagger$ Alterra, Wageningen University and Research Center, and \\ $\S$ Wageningen Institute of Animal Sciences, Animal Nutrition Group, Wageningen University, 6700 Wageningen, the Netherlands
}

\begin{abstract}
Knowledge of the effects of cow diet on manure composition is required to improve nutrient use efficiency and to decrease emissions of $\mathrm{N}$ to the environment. Therefore, we performed an experiment with nonlactating cows to determine the consequences of changes in cow rations for the chemical characteristics and the traits of the microbial community in the feces. In this experiment, 16 cows were fed 8 diets, differing in crude protein, neutral detergent fiber, starch, and net energy content. These differences were achieved by changing dietary ingredients or roughage to concentrate ratio. After an adaptation period of $3 \mathrm{wk}$, fecal material was collected and analyzed. Observed results were compared with simulated values using a mechanistic model that provides insight into the mechanisms involved in the effect of dietary variation on fecal composition. Feces produced on a high-fiber, low-protein diet had a high C:N ratio $(>16)$ and had lower concentrations of both organic and inorganic $\mathrm{N}$ than feces on a low-fiber, high-protein diet. Fecal bacterial biomass concentration was highest in high-protein, high-energy diets. The fraction of inorganic $\mathrm{N}$ in the feces was not significantly different between the different feces. Microbial biomass in the feces ranged from 1,200 to $8,000 \mu \mathrm{g}$ of $\mathrm{C} / \mathrm{g}$ of dry matter (average: $3,700 \mu \mathrm{g}$ of $\mathrm{C} / \mathrm{g}$ of dry matter). Bacterial diversity was similar for all fecal materials, but the different protein levels in the feeding regimens induced changes in the community structure present in the different feces. The simulated total $\mathrm{N}$ content $\left(\mathrm{N}_{\text {total }}\right)$ in the feces ranged from 1.0 to 1.5 times the observed concentrations, whereas the simulated C: $\mathrm{N}_{\text {to- }}$ tal of the feces ranged from 0.7 to 0.9 times the observed $\mathrm{C}: \mathrm{N}_{\text {total }}$. However, bacterial biomass $\mathrm{C}$ was not predicted satisfactorily (simulated values being on average 3 times higher than observed), giving rise to further
\end{abstract}

Received January 30, 2007.

Accepted July 24, 2007.

${ }^{1}$ Corresponding author: Petra.vanvliet@wur.nl discussion on the definition of microbial $\mathrm{C}$ in feces. Based on these observations, it was concluded that diet composition affected fecal chemical composition and microbial biomass. These changes may affect the nutrient use and efficiency of the manure. Because the present experiment used a limited number of dry cows and extreme diet regimens, extrapolation of results to other dairy cow situations should be done with care.

Key words: DNA fingerprinting, manure composition, bacterial diversity, dairy farming

\section{INTRODUCTION}

In many agricultural systems, manure slurry is used as fertilizer. The manure slurry consists of a mixture of feces and urine and contains inorganic $\left(\mathbf{N}_{\text {inorg }}\right)$ and organic $\mathrm{N}$ ( $\mathbf{N}_{\text {org. }}$ ). The $\mathrm{N}_{\text {org }}$ has to be mineralized before it is available for plant uptake. During microbial decomposition of organic compounds in applied slurry, part of the ammonium $\mathrm{N}$ will be immobilized in the soil (Sørensen and Jensen, 1995), whereas another part will be lost from the soil system. Dietary adjustments have often been suggested as a means to reduce $\mathrm{N}$ losses from dairy systems (Børsting et al., 2003). The N mineralization-immobilization processes occurring in the soil are influenced by the slurry composition and affect the fertilizing value of slurry. Janssen (1996) showed that for substances with equal decomposability, net mineralization linearly decreased with increasing C:N ratio of the organic material. Ruminant fecal $\mathrm{N}$ concentration has been shown to decrease with diet digestibility (Kyvsgaard et al., 2000; Sørensen et al., 2003). Therefore, diet digestibility is probably a determining factor for the $\mathrm{C}: \mathrm{N}_{\text {org }}$ ratio of slurry. An immediately apparent dietary adjustment is the lowering of dietary CP content. As reviewed by Castillo et al. (2000), a reduction in dietary CP level from 200 to $150 \mathrm{~g} / \mathrm{kg}$ of DM decreased $\mathrm{N}$ excretion in feces by $21 \%$ and $\mathrm{N}$ excretion in urine by $66 \%$. Previous simulation studies by Kebreab et al. (2002) showed that an increase in dietary fermentable energy content at a similar $\mathrm{N}$ intake level resulted in 
a larger amount of $\mathrm{N}$ excreted in the feces and an even more pronounced decline of $\mathrm{N}$ excreted in urine. Changes in protein degradability marginally affected fecal $\mathrm{N}$ output. In the Dutch VEL and VANLA project (Verhoeven et al., 2003), a decrease of the ratio of urinary to fecal $\mathrm{N}$ output is advocated through a minimization of the ruminal degraded protein balance (Tamminga et al., 1994) and an increase of the dietary fiber content. The latter is expected to increase the excretion of poorly degradable endogenous $\mathrm{N}$ present in mucus, sloughed off epithelial cells, and pancreatic secretions in the gut (van Bruchem and Tamminga, 1997) by an increased passage of organic material. Also, microbial production in the hindgut may be increased upon an increased supply of potentially fermentable fiber that will partly reach the hindgut. Hence, a shift in N excretion may occur from urine to feces. Such dietary adjustments will not only result in a different chemical composition of feces and urine, but the availability of manure $\mathrm{N}$ for the plant (Sørensen et al., 2003) will also be affected.

Integrated and quantitative information on the effect of dietary changes on excreta composition might therefore be helpful to improve the utilization of manure $\mathrm{N}$. However, current feed evaluation systems are still largely focused on the output of milk, and the prediction of manure composition is not of major concern. Furthermore, energy and protein evaluation systems are empirically based and have been developed independently, despite vast evidence of the interactions between energy- and protein-yielding nutrients in the gastrointestinal tract of ruminants. Therefore, these systems are unlikely to predict effects of dietary changes upon manure composition accurately (Dijkstra et al., 2007). Recently, Reijs (2007) developed an integrated model that predicts the composition of excreta as a function of diet composition. Excreta composition comprises $\mathrm{OM}$ and $\mathrm{C}$ and $\mathrm{N}$ output with different fecal and urinary components.

Besides chemical changes, changes in the fecal microbial community also may be expected from dietary adjustments as the diet affects nutrient flow into the hindgut and hence likely affects the microbial community there. Information on differences in fecal microbial community as a result of dietary changes might also contribute to the understanding of differences in the fertilization potential of different manures. Microorganisms in ruminants are primarily involved in decomposition of the feed and the $\mathrm{N}$ metabolism in the animal. Feeds with abundant foliage contain a large amount of protein, which is degraded in the rumen, and when not enough rumen-fermentable energy is present, it is excreted in urine. In the case of low-energy contents, microbial growth in the rumen, in the large intestine, and in the feces will be $\mathrm{C}$ - rather than N-limited. When sufficient degradable carbohydrate is present, microorganisms can utilize a large fraction of this protein and keep the $\mathrm{N}$ in organic form. Moreover, recycling of $\mathrm{N}$ by urea entering the rumen with saliva or through the rumen or hindgut wall further increases the dietary situations of C-limited growth in both rumen and hindgut (Dijkstra et al., 2002).

Numerous literature references on pathogenic organisms in manure can be found (Pell, 1997; Stoddard et al., 1998), but information considering abundances of naturally occurring bacteria in slurry manures is limited. In swine manure, $2 \times 10^{11} \mathrm{bacteria} / \mathrm{g}$ of fresh weight (Cotta et al., 2003) or $1 \times 10^{10}$ cells/mL (Leung and Topp, 2001) were counted. Until now, no detailed analyses of the microbial community structure, biomass, and activity in cow feces have been published. Molecular techniques for detecting and identifying microorganisms by certain molecular markers have become available and are frequently used to explore the microbial diversity. Using molecular techniques, including sequencing, Ouwerkerk and Klieve (2001) found that $16.3 \%$ of the total number of species were predominating culturable species in cattle manure. Also, the frequency of detection of novel bacteria in manure was much higher using molecular techniques. Fingerprints created by the denaturating gradient gel electrophoresis (DGGE) technique can be used for monitoring shifts in community structure (Muyzer and Smalla, 1998; Zoetendal et al., 2004).

We have examined the consequences of changes in cow rations for the chemical characteristics and the biomass, activity, and structure of the microbial community in the feces. For this experiment, 8 different diets with high and low levels of dietary protein and net energy were created with different forage types (Reijs et al., 2007). We also related our results to predictions using a mechanistic model of fermentation and digestion in the gastrointestinal tract of ruminants (Reijs, 2007). These research questions have led to the following hypotheses:

1) Cow diets with reduced protein and increased fiber content lead to more $\mathrm{N}$ assimilation in bacterial biomass and less excretion of $\mathrm{N}_{\text {inorg }}$ with feces.

2) Diets with reduced $N$ availability will select for bacteria with a higher $\mathrm{N}$ assimilation efficiency, which will be reflected in a different bacterial community structure. In a diet high in fiber (straw, mature grass silage), the presence of complex molecules that are not fermented in the rumen and reach the hindgut will result in a higher microbial diversity. 
Table 1. Coding of the different diets used in the study and their dietary characteristics ${ }^{1}$

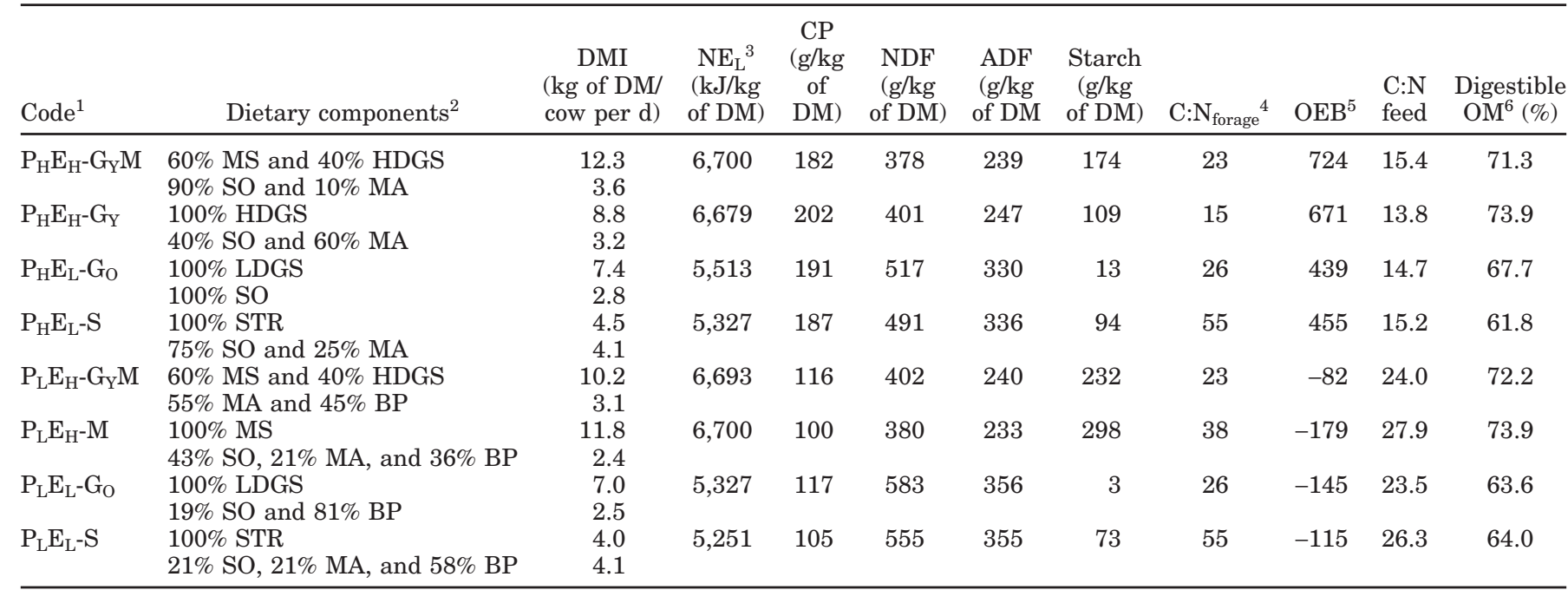

\footnotetext{
${ }^{1} \mathrm{P}_{\mathrm{H}}=$ high protein; $\mathrm{P}_{\mathrm{L}}=$ low protein $; \mathrm{E}_{\mathrm{H}}=$ high energy $\mathrm{E}_{\mathrm{L}}=$ low energy; $\mathrm{G}_{\mathrm{Y}}=$ young grass silage; $\mathrm{G}_{\mathrm{O}}=$ old grass silage; $\mathrm{M}=$ maize; $\mathrm{S}=$ straw.

${ }^{2} \mathrm{BP}=$ beet pulp; HDGS = high digestible grass silage; LDGS = low digestible grass silage; $\mathrm{MA}=$ maize MS = maize silage; $\mathrm{SO}=$ soybean meal; STR = straw .

${ }^{3}$ Calculated from original feed evaluation.

${ }^{4} \mathrm{C}: \mathrm{N}_{\text {forage }}=$ total $\mathrm{C}: \mathrm{N}$ ratio of the forage.

${ }^{5} \mathrm{OEB}=$ degraded protein balance in the rumen ( $\mathrm{g} / \mathrm{d}$ ) calculated according to Tamminga et al. (1994).

${ }^{6}$ Calculated as follows: [ingested OM (in kg) - OM in slurry at the end of the collection period (in kg)]/ingested OM (in kg) $\times 100 \%$.
}

3) The data produced in this study will corroborate the mechanistic model.

\section{MATERIALS AND METHODS}

\section{Feeding Regimens}

The experiment was conducted at the experimental farm De Meenthoeve (Rhenen, the Netherlands) in February 2003, and 16 nonlactating Holstein-Friesian cows were used. The experiment is briefly described; further details can be found in Reijs et al. (2007). The cows were divided into pairs and fed 8 different diets (Table 1). Cows were fed ad libitum twice daily (morning and evening); food not consumed was removed and weighed before fresh food was supplied. No bedding material was used. A 3-wk adaptation period was applied before the start of the experiment. The diets differed in forage and concentrate type and contained 2 levels of $\mathrm{CP}$ and 2 levels of $\mathrm{NE}_{\mathrm{L}}$. The $2 \mathrm{CP}$ levels (high: $\approx 182$ to $202 \mathrm{~g} /$ $\mathrm{kg}$ of DM; low $\approx 100$ to $117 \mathrm{~g} / \mathrm{kg}$ of DM) were combined with $2 \mathrm{NE}_{\mathrm{L}}$ levels (high: $\approx 6.6$ to $6.7 \mathrm{MJ} / \mathrm{kg}$ of $\mathrm{DM}$; low: $\approx 5.3$ to $5.5 \mathrm{MJ} / \mathrm{kg}$ of $\mathrm{DM}$ ). The 2 regimens at the high $\mathrm{NE}_{\mathrm{L}}$ level differed slightly in the proportion of NDF, $\mathrm{ADF}$, and starch level (Table 1). After the adaptation period, feces of the 16 cows were collected for chemical and microbiological analyses during $1 \mathrm{~d}$. In case any diurnal pattern in the fecal composition was present, the quantitative sampling ensured a proper average sample of a full day. Part of the feces was frozen at $-20^{\circ} \mathrm{C}$ for DNA analysis; the remaining feces were stored at $4^{\circ} \mathrm{C}$ for other microbiological and chemical analyses for a short period.

\section{Chemical Analyses of the Feed and the Feces}

Chemical analyses were started 3 wk after collection of the feces. Before determination of the DM content, all feces samples were acidified to a $\mathrm{pH}<4$ using 6 $M \mathrm{HCl}$ to prevent volatilization of ammonia. The DM fraction was determined by drying the acidified feces at $105^{\circ} \mathrm{C}$ for $3 \mathrm{~d}$. For nutrient analyses, acidified feces were dried at $70^{\circ} \mathrm{C}$ for $1 \mathrm{~d}$ and ground with pestle and mortar. Part of this ground material was milled to $<250$ $\mu \mathrm{m}$ and analyzed for total $\mathrm{C}\left(\mathbf{C}_{\text {total }}\right)$ and $\mathrm{N}$ on a Fisons Instruments EA $1108 \mathrm{CHN}$ analyzer, with a Porapak QS column with He as carrier gas and a thermal conductivity gas detector (Interscience, Breda, the Netherlands). Inorganic $\mathrm{N}$ concentrations $\left(\mathrm{NO}_{3}{ }^{-}\right.$and $\left.\mathrm{NH}_{4}{ }^{+}\right)$in the ground, dried acidified feces were determined using a water extraction (Houba et al., 1997). The OM content of the feces was determined using the loss-on-ignition method (Houba et al., 1997).

Feed samples were analyzed for total $\mathrm{N}\left(\mathbf{N}_{\text {total }}\right)$, using the CE Instruments EA $1110 \mathrm{CHN}$ analyzer (CE Instru- 
ments, Milan, Italy) after freeze-drying. Crude protein in the feed was calculated as $\mathrm{N}_{\text {total }} \times 6.25$. The NDF and $\mathrm{ADF}$ were analyzed with amylase after freeze-drying according to Van Soest et al. (1991) and expressed on an ash-free basis. Feed starch was determined using a hot ethanol extraction, $\alpha$-amylase, and amyloglucosidase and measured on a HPLC. The degraded protein balance in the rumen $(\mathrm{g} / \mathrm{d})$ was calculated according to Tamminga et al. (1994). The digested OM percentage was calculated as the ingested OM (in $\mathrm{kg} / \mathrm{d}$ ) minus the $\mathrm{OM}$ in the slurry at the end of the collection period (in $\mathrm{kg} / \mathrm{d}$ ) divided by ingested $\mathrm{OM}$ (in $\mathrm{kg} / \mathrm{d}$ ) multiplied by $100 \%$.

\section{Microbial Analyses}

Microbiological analyses were started the day after collection of the feces. The total number of bacteria and several morphological characteristics of the microbial community were determined in a feces smear using confocal laser scanning microscopy and image analysis (Bloem et al., 1995b). Bacterial biomass was calculated using the total number and the average cell volume of the fluorescently stained bacteria combined with a specific C content of $3.1 \times 10^{-13} \mathrm{~g}$ of $\mathrm{C} / \mu \mathrm{m}^{3}$ (Fry, 1990). The preparation of the feces smear was similar to the preparation of soil smears as described in Bloem et al. (1995a). In summary, for each fecal sample, $20 \mathrm{~g}$ of fresh fecal material was homogenized with $190 \mathrm{~mL}$ of deionized water in a blender for $2 \mathrm{~min}$. A 9-mL sample of the fecal suspension was fixed by adding $1 \mathrm{~mL}$ of $37 \%$ formaldehyde. The suspensions were diluted 10 times, after which $10 \mu \mathrm{L}$ was applied (after shaking and a settling time of $2 \mathrm{~min}$ ) to printed microscopy slides with a $12-\mathrm{mm}$ well. After a drying time of $1 \mathrm{~h}$ at $50^{\circ} \mathrm{C}$, staining, destaining, and mounting the smears were done as described by Bloem et al. (1995a). Each fecal sample was analyzed in duplicate.

Bacterial growth rates were determined using the incorporation of ${ }^{14} \mathrm{C}-\mathrm{Leu}$ (Michel and Bloem, 1993; Bloem and Bolhuis, 2006). Leucine is an AA that is incorporated in proteins. The bacterial growth rate is reflected by the incorporation rate of ${ }^{14} \mathrm{C}$-Leu into proteins during a short incubation of $1 \mathrm{~h}$. If the incubation is short enough, growth rate is not affected by the incubation. Briefly, $20 \mathrm{~g}$ of fecal material was homogenized in $95 \mathrm{~mL}$ of mineral medium. From this diluted fecal suspension, $100 \mu \mathrm{L}$ was added to $20 \mu \mathrm{L}$ of labeled ${ }^{14} \mathrm{C}$ Leu ( $2 \mu M$ final concentration) and incubated for $1 \mathrm{~h}$. Proteins were extracted overnight in a warm base solution. Particles were removed by centrifugation, and proteins were precipitated by cold acid and collected on a filter. Radioactivity was measured, and Leu incorporation was calculated.
The DNA was extracted from the feces using a FastDNA SPIN Kit (BIO 101 Qbiogene, Carlsbad, CA) normally used to extract DNA from soil. In the extraction, 0.10 to $0.17 \mathrm{~g}$ of fecal material was used. If necessary, samples were purified using the Wizard DNA Clean Up System (Promega, Madison, WI). Of the DNA extract, $1 \mu \mathrm{L}$ was used in the PCR (Dilly et al., 2004). The variable V3 region of $16 \mathrm{~S}$ rRNA gene sequences from nucleotide 341 to nucleotide 534 (Escherichia coli numbering) was amplified by PCR using eubacterial primers 2 and 3 and the hot start-touchdown protocol with a total of 30 cycles as described by Muyzer et al. (1993). A $2 \%$ agarose gel was used to check the result of the PCR and to determine the amount of DNA that should be used for the DGGE. Equal amounts of DNA were loaded onto an $8 \%$ polyacrylamide gel with a 40 to $75 \%$ denaturant (urea-formamide) gradient (Dilly et al., 2004).

The fingerprints generated with the DGGE were analyzed for similarity using GelCompar II (Applied Maths, Kortrijk, Belgium). The unweighted paired group method using arithmetic averages in combination with Jaccard coefficient and the Pearson coefficient was used for determination of similarity matrices of the different fingerprints. Jaccard's coefficient is based on the presence of bands in pairs of fingerprints; absence of a band in both fingerprints is not accounted for. Pearson's coefficient is based on the presence and height of bands in pairs of fingerprints. The intensity of the DNA band is an indication of the amount of DNA present: a thicker band implies more DNA and a greater number of cells per bacterial species.

The fingerprint data were used to calculate the Shannon-Wiener diversity index $\left(\mathrm{H}^{\prime}\right)$ which was calculated as:

$$
H^{\prime}=-\sum_{i=1}^{S}\left(n_{i} / N\right) \times \ln \left(n_{i} / N\right)
$$

where $S=$ the number of DNA bands; $n_{i}=$ the mass of the $i$ th DNA band; and $N=$ the total mass of all bands (Atlas and Bartha, 1987). The mass of a DNA band was calculated by multiplying the width of the band with the signal intensity (gray level) of the band. The ShannonWiener diversity index is a general diversity index that is sensitive to the number of species and the relative species abundance (Atlas and Bartha, 1987). For further analysis, we have assumed that the number of bands present on a DGGE gel represents the number of bacterial species present. Dilly et al. (2004) and Dolfing et al. (2004) have shown that, in general, the number of DNA bands present on a fingerprint reflects the number of bacterial species, whereas the intensity 
Table 2. Chemical and microbiological characteristics of the feces collected from the different $\operatorname{diets}^{1}$

\begin{tabular}{lccccccc}
\hline Treatment & $\begin{array}{c}\mathrm{DM} \\
(\%)\end{array}$ & C: $\mathrm{N}_{\text {org }}$ & $\begin{array}{c}\mathrm{C}_{\text {total }} \\
(\mathrm{g} / \mathrm{kg} \text { of DM) }\end{array}$ & $\begin{array}{c}\mathrm{N}_{\text {inorg }} \\
(\mathrm{g} / \mathrm{kg} \text { of } \mathrm{DM})\end{array}$ & $\begin{array}{c}\mathrm{N}_{\text {inorg }} \\
(\%)\end{array}$ & $\begin{array}{c}\text { DNA } \\
\text { bands }\end{array}$ & $\begin{array}{c}\text { SW } \\
\text { index }\end{array}$ \\
\hline $\mathrm{P}_{\mathrm{H}} \mathrm{E}_{\mathrm{H}}-\mathrm{G}_{\mathrm{Y}} \mathrm{M}$ & 13.4 & $15.3^{\mathrm{de}}$ & $427.9^{\mathrm{ab}}$ & $2.5^{\mathrm{a}}$ & 8.1 & 41.0 & 3.5 \\
$\mathrm{P}_{\mathrm{H}} \mathrm{E}_{\mathrm{H}}-\mathrm{G}_{\mathrm{Y}}$ & 15.3 & $12.1^{\mathrm{e}}$ & $422.5^{\mathrm{ab}}$ & $2.0^{\mathrm{ab}}$ & 5.3 & 38.5 & 3.4 \\
$\mathrm{P}_{\mathrm{H}} \mathrm{E}_{\mathrm{L}}-\mathrm{G}_{\mathrm{O}}$ & 17.8 & $18.3^{\mathrm{bcd}}$ & $391.4^{\mathrm{c}}$ & $1.6^{\mathrm{bc}}$ & 6.8 & 39.0 & 3.4 \\
$\mathrm{P}_{\mathrm{H}} \mathrm{E}_{\mathrm{L}}-\mathrm{S}$ & 12.4 & $23.7^{\mathrm{ab}}$ & $437.7^{\mathrm{ab}}$ & $1.5^{\mathrm{bc}}$ & 7.6 & 37.5 & 3.3 \\
$\mathrm{P}_{\mathrm{L}} \mathrm{E}_{\mathrm{H}}-\mathrm{G}_{\mathrm{Y}} \mathrm{M}$ & 14.7 & $16.9^{\text {cde }}$ & $4304^{\mathrm{ab}}$ & $1.6^{\mathrm{bc}}$ & 5.8 & 36.5 & 3.4 \\
$\mathrm{P}_{\mathrm{L}} \mathrm{E}_{\mathrm{H}}-\mathrm{M}$ & 14.2 & $23.4^{\mathrm{ab}}$ & $432.3^{\mathrm{ab}}$ & $1.7^{\mathrm{bc}}$ & 8.2 & 41.0 & 3.5 \\
$\mathrm{P}_{\mathrm{L}} \mathrm{E}_{\mathrm{L}}-\mathrm{G}_{\mathrm{O}}$ & 18.5 & $21.0^{\mathrm{abc}}$ & $352.4^{\mathrm{c}}$ & $1.1^{\mathrm{c}}$ & 6.2 & 35.5 & 3.4 \\
$\mathrm{P}_{\mathrm{L}} \mathrm{E}_{\mathrm{L}}-\mathrm{S}$ & 14.0 & $26.0^{\mathrm{a}}$ & $407.1^{\mathrm{bc}}$ & $1.0^{\mathrm{c}}$ & 5.9 & 38.0 & 3.5 \\
$\mathrm{SEM}$ & 0.6 & 1.2 & 7.0 & 0.1 & 0.3 & 0.6 & 0.02 \\
\hline
\end{tabular}

${ }^{a-e}$ Different letters within a column denote significant differences between the treatments $(P<0.05)$.

${ }^{1}$ Bacterial diversity as indicated by the number of DNA bands and the Shannon-Wiener (SW) index (means, $\mathrm{n}=2$ ). $\mathrm{N}_{\text {org }}=$ organic $\mathrm{N} ; \mathrm{C}_{\text {total }}=$ total $\mathrm{C}$ content of feces; $\mathrm{N}_{\text {inorg }}=$ inorganic $\mathrm{N}$.

${ }^{2} \mathrm{P}_{\mathrm{H}}=$ high protein; $\mathrm{P}_{\mathrm{L}}=$ low protein; $\mathrm{E}_{\mathrm{H}}=$ high energy; $\mathrm{E}_{\mathrm{L}}=$ low energy; $\mathrm{G}_{\mathrm{Y}}=$ young grass silage; $\mathrm{G}_{\mathrm{O}}=$ old grass silage; $\mathrm{M}=$ maize; $\mathrm{S}=$ straw.

of the band strongly correlates with relative amounts of the different species.

\section{Statistical Analyses}

For statistical analysis of the chemical and biological data, SAS/STAT version 9.1 (SAS Institute Inc., Cary, NC) was used (ANOVA, correlations). Before analysis, all variables were checked for normality and transformed if necessary. The Tukey posthoc test was used to determine significant differences between the different fecal materials.

The observed chemical and microbial data of the feces were compared with predictions using the model described by Reijs (2007). This model comprises a mechanistic part describing the rumen fermentation processes, extended with equations to describe the digestion and fermentation processes in the small and large intestine. The model predicts $\mathrm{OM}, \mathrm{C}$, and $\mathrm{N}$ (organic and inorganic) output in feces and urine. The mean square prediction error (MSPE) was used to assess the error of predicted relative to the observed values:

$$
M S P E=\sum_{i=1}^{n}\left(O_{i}-\mathrm{P}_{i}\right)^{2} / n,
$$

where $i=1,2, \ldots . \mathrm{n} ; n=$ the number of experimental observations ( $\mathrm{n}=16)$; and $O_{i}$ and $P_{i}=$ the observed and predicted value of the ith observation, respectively. The square root of the MSPE is expressed in the same units as the observed values. Comparing the root MSPE as a percentage of the observed mean provides an indication of the overall error of prediction.

Residual plots showing the predicted value vs. the difference between observed and predicted values were used to evaluate the simulation model. For prediction bias analyses, the regressor used in the equations was shifted and centralized to its mean value. In this method, the intercept and slope estimates are independent of each other and $t$-tests can be used to determine the bias of the model. The intercept term measures the overall prediction bias, whereas the slope of the regression is an estimate of the linear prediction bias (St-Pierre, 2003).

\section{RESULTS}

\section{Chemical Composition of the Feces and the Slurry Manure}

The DM contents of the 8 fecal materials were not significantly statistically different (Table 2). Numerically, the diets based on old grass silage $\left(\mathbf{G}_{\mathbf{O}} ; \mathrm{P}_{\mathrm{H}} \mathrm{E}_{\mathrm{L}}-\mathrm{G}_{\mathrm{O}}\right.$ and $\mathrm{P}_{\mathrm{L}} \mathrm{E}_{\mathrm{L}}-\mathrm{G}_{\mathrm{O}}$ ) had a higher average $\mathrm{DM}$ content.

There were significant differences in $\mathrm{C}_{\text {total }}(\mathrm{g} / \mathrm{kg}$ of DM) content between feces. The interaction between $\mathrm{NE}_{\mathrm{L}}$ and $\mathrm{CP}$ was not significant. With an increase in $\mathrm{NE}_{\mathrm{L}}$, the $\mathrm{C}_{\text {total }}$ increased significantly $(P=0.012)$. No effect of CP was present. The difference was mainly caused by the low $\mathrm{C}_{\text {total }}$ content of both old grass silage treatments. The concentration of $\mathrm{N}_{\text {total }}$ (in $\mathrm{g} / \mathrm{kg}$ of $\mathrm{OM}$ ) in $\mathrm{P}_{\mathrm{H}} \mathrm{E}_{\mathrm{H}^{-}} \mathrm{G}_{\mathrm{Y}}$ and $\mathrm{P}_{\mathrm{H}} \mathrm{E}_{\mathrm{H}^{-}}-\mathrm{G}_{\mathrm{Y}} \mathrm{M}$ was higher $(P=0.001)$ compared with the other treatments (Figure 1A). A higher $\mathrm{N}_{\text {total }}$ concentration coincided with a higher $\mathrm{N}_{\text {org }}$ concentration (Pearson $=0.999, P<0.001$ ). An increase in the $\mathrm{N}_{\text {total }}$ concentration also coincided with a higher concentration of $\mathrm{N}_{\text {inorg }}$ in the feces (Pearson $=0.751$, $P=0.001$ ). For all 8 feces types, $\mathrm{N}_{\text {inorg }}$ was about 5 to $8 \%$ of the $\mathrm{N}_{\text {total }}$ content (Table 2 ).

The C: $\mathrm{N}_{\text {total }}$ ratio (Figure $1 \mathrm{~B}$ ) and the $\mathrm{C}: \mathrm{N}_{\text {org }}$ ratio (Table 2) differed significantly for the different feces. With an increasing $\mathrm{CP}$ and $\mathrm{NE}_{\mathrm{L}}$, the $\mathrm{C}: \mathrm{N}_{\text {total }}$ and $\mathrm{C}: \mathrm{N}_{\text {org }}$ ratios decreased significantly (interactions were not significant.). The feces from the low-protein diets combined with straw, maize (Zea mays), or mature grass silage, 


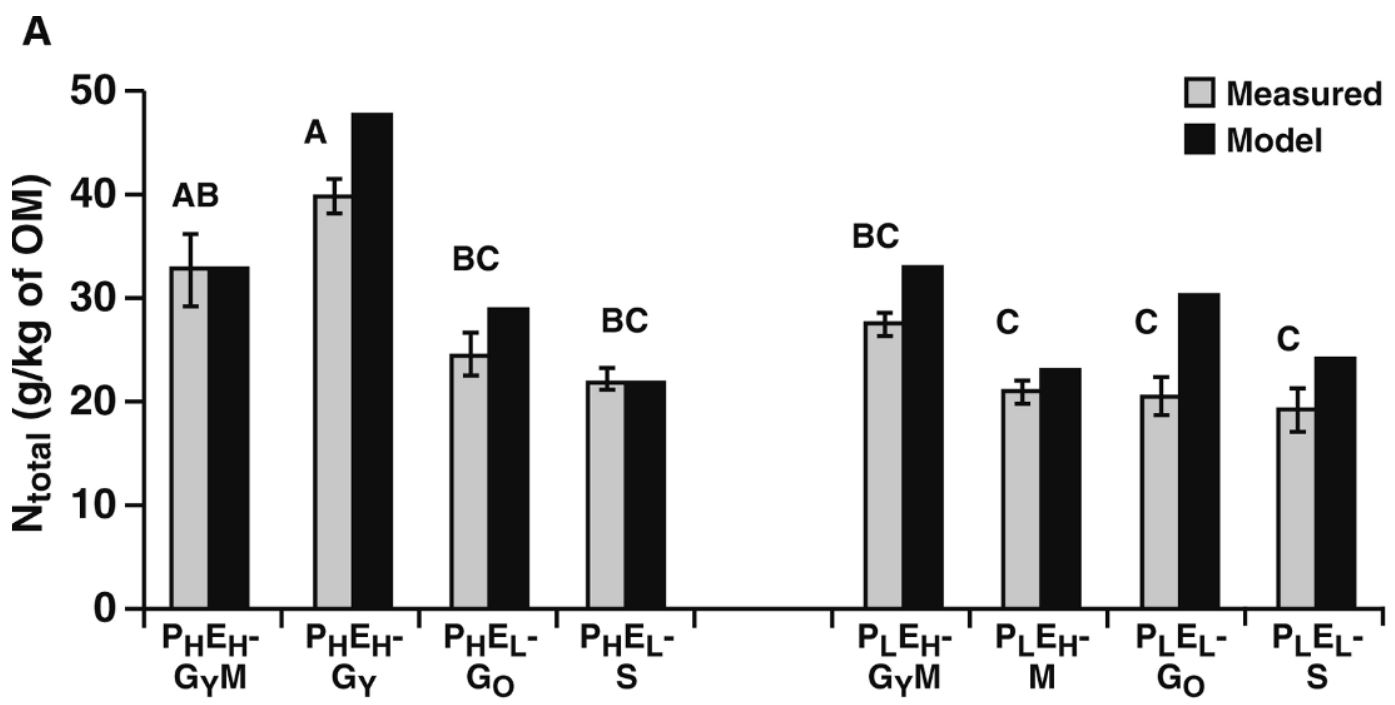

B

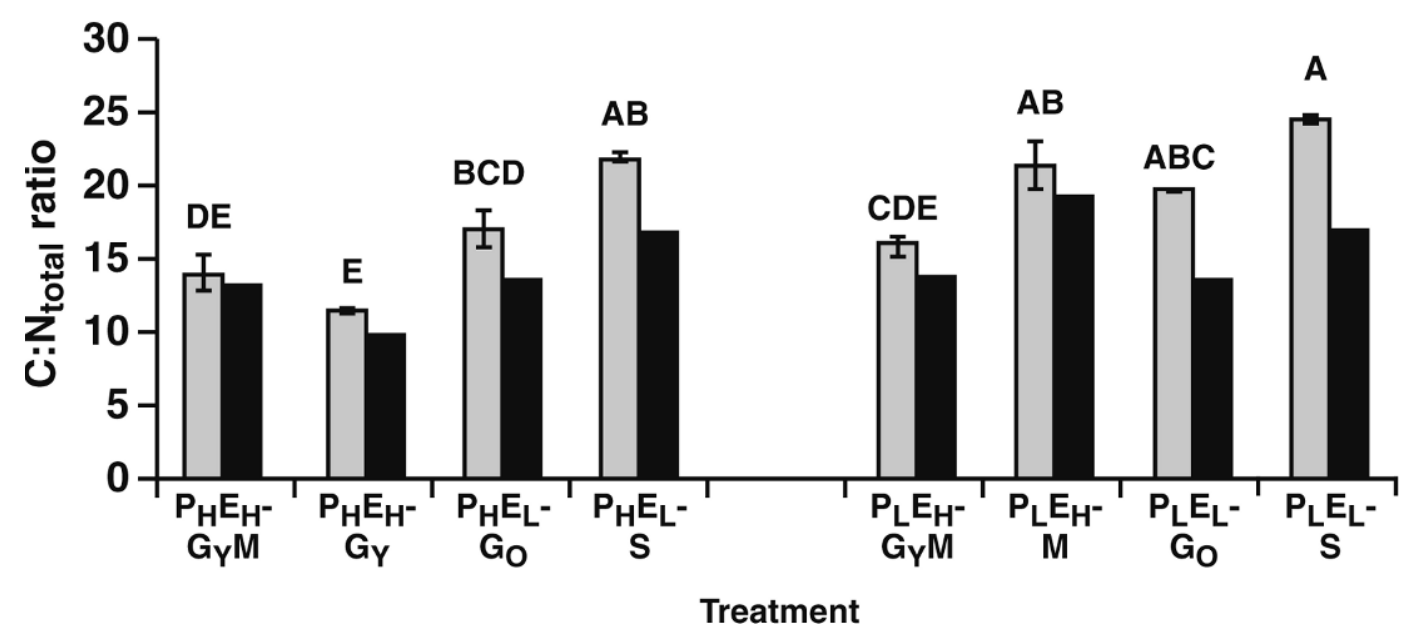

Figure 1. Chemical characteristics of the fecal material of cows fed different diets (average and standard error). A) Measured and predicted concentration of total $\mathrm{N}$ content of feces $\left(\mathrm{N}_{\text {total }}\right)$ in grams per kilogram of OM; SEM (measured) $=1.81$. B) Measured and predicted $\mathrm{C}: \mathrm{N}_{\text {total }}$ ratio; $\mathrm{SEM}$ (measured) $=1.09 .{ }^{\mathrm{A}-\mathrm{E}}$ Letters in a graph denote significant differences between the measured data of the treatments $(P$ $<0.05)$. $\mathrm{P}_{\mathrm{H}}=$ high protein; $\mathrm{P}_{\mathrm{L}}=$ low protein $; \mathrm{E}_{\mathrm{H}}=$ high energy; $\mathrm{E}_{\mathrm{L}}=$ low energy; $\mathrm{G}_{\mathrm{Y}}=$ young grass silage; $\mathrm{G}_{\mathrm{O}}=$ old grass silage; $\mathrm{M}=$ maize; $\mathrm{S}=$ straw.

or the high-protein with straw feeding regimen had a high $\mathrm{C}: \mathrm{N}_{\text {total }}$ ratio. The diet high in protein combined with young grass silage $\left(\mathrm{P}_{\mathrm{H}} \mathrm{E}_{\mathrm{H}}-\mathrm{G}_{\mathrm{Y}}\right)$ had the lowest $\mathrm{C}: \mathrm{N}_{\text {to- }}$ tal and $\mathrm{C}: \mathrm{N}_{\text {org }}$ ratio.

\section{Bacterial Diversity in the Feces}

The bacterial diversity in the feces was similar $(P>$ $0.05)$ for all diets. The number of DNA bands ranged from $35.5\left(\mathrm{P}_{\mathrm{L}} \mathrm{E}_{\mathrm{L}}-\mathrm{G}_{\mathrm{O}}\right)$ to $41\left(\mathrm{P}_{\mathrm{L}} \mathrm{E}_{\mathrm{H}}-\mathrm{M}\right.$ and $\left.\mathrm{P}_{\mathrm{H}} \mathrm{E}_{\mathrm{H}}-\mathrm{G}_{\mathrm{Y}} \mathrm{M}\right)$, and the Shannon-Wiener index was around 3.4 (Table 2 ). The similarity in species composition of the 16 analyzed feces based on the presence and absence of DNA bands (Jaccard coefficient) varied from 64 to $92 \%$. A
Jaccard coefficient of $100 \%$ implies complete similarity, whereas a coefficient of 0 implies no similarity at all between the different samples. Cluster analysis with the Jaccard coefficient showed no clear effects of the different diets on the species composition in the produced feces (data not shown). If the relative abundance of the present bacterial species (equal intensity of the bands) was taken into account (in the Pearson coefficient), a clear separation in protein level was visible (Figure 2).

\section{Bacterial Biomass and Production}

Bacterial numbers in the different feces ranged from $1.1 \times 10^{10}\left(\mathrm{P}_{\mathrm{H}} \mathrm{E}_{\mathrm{H}^{-}} \mathrm{G}_{\mathrm{O}}\right)$ to $9.3 \times 10^{10}\left(\mathrm{P}_{\mathrm{H}} \mathrm{E}_{\mathrm{H}^{-}} \mathrm{G}_{\mathrm{M}}\right)$ cells $\mathrm{g}$ of 


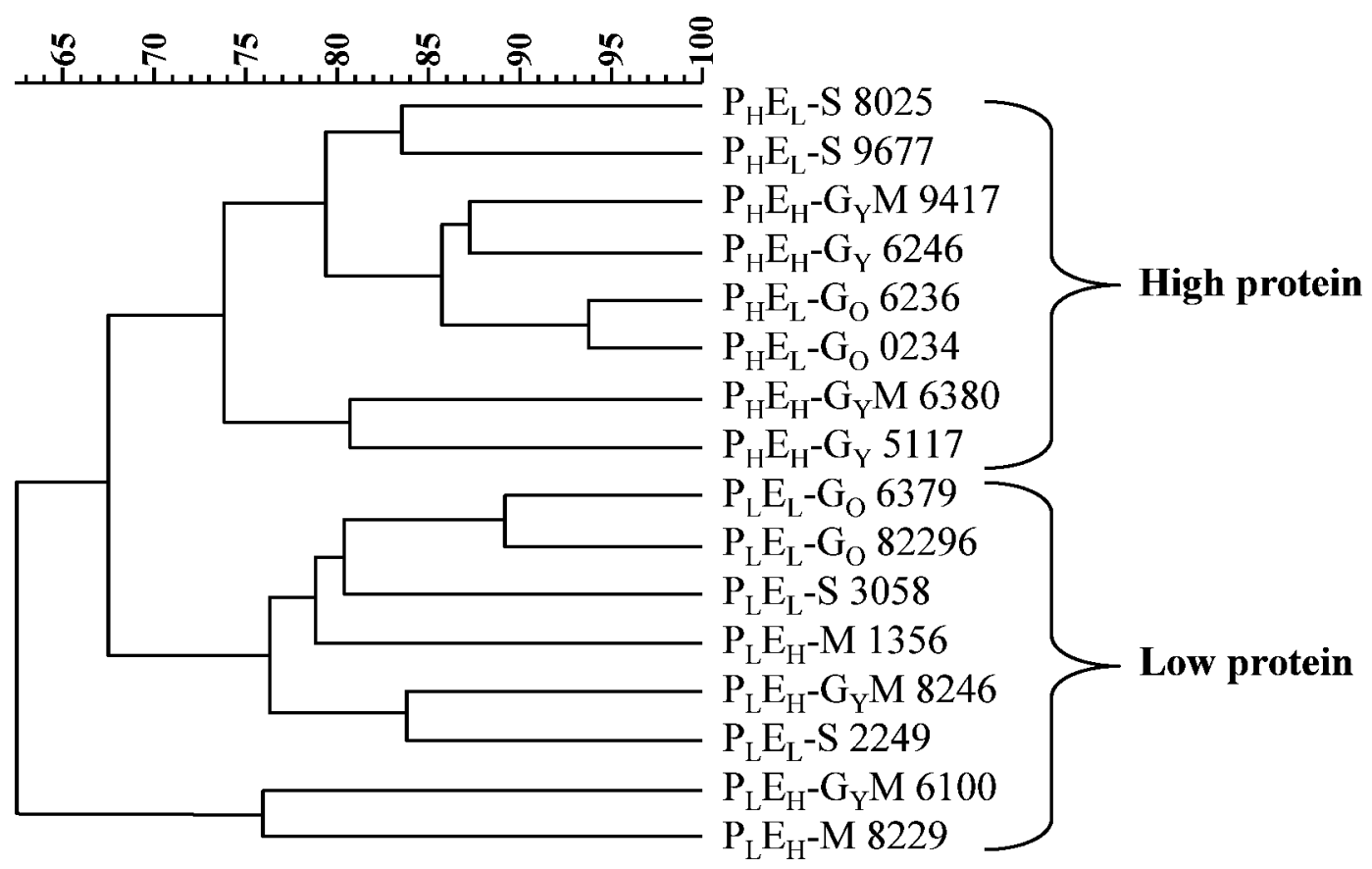

Figure 2. Dendrogram of bacterial DNA bands present in the 16 different fecal materials ( 8 feeding regimens, 2 cows/regimen) based on the Pearson coefficient. In the calculation of the Pearson coefficient, species composition and biomass are combined. The ruler shows the similarity between the different feces. $\mathrm{P}_{\mathrm{H}}=$ high protein; $\mathrm{P}_{\mathrm{L}}=$ low protein; $\mathrm{E}_{\mathrm{H}}=$ high energy; $\mathrm{E}_{\mathrm{L}}=$ low energy; $\mathrm{G}_{\mathrm{Y}}=$ young grass silage; $\mathrm{G}_{\mathrm{O}}=$ old grass silage; $\mathrm{M}=$ maize; $\mathrm{S}=$ straw. The numbers next to the codes refer to the different cows.

DM. Microbial biomass in the feces ranged from 1,200 to $8,000 \mu \mathrm{g}$ of $\mathrm{C} / \mathrm{g}$ of $\mathrm{DM}$ (average: $3,700 \mu \mathrm{g}$ of $\mathrm{C} / \mathrm{g}$ of $\mathrm{DM}$ ). In figure $3 \mathrm{~A}$, bacterial biomass (in $\mathrm{g}$ of $\mathrm{C} / \mathrm{kg}$ of $\mathrm{OM}$ ) in the 8 different treatments is shown. A higher biomass in the feces was found with the feeding regimens containing a high energy level $(P=0.008)$. However, the interaction between protein and energy was significant $(P=0.04)$. This interaction occurs because feces of high-energy diets have higher microbial biomass at high dietary protein levels but not at low dietary protein levels. The feces produced on diets that combine a high energy and high protein level $\left(\mathrm{P}_{\mathrm{H}} \mathrm{E}_{\mathrm{H}^{-}}\right.$ $\mathrm{G}_{\mathrm{Y}} \mathrm{M}$ and $\mathrm{P}_{\mathrm{H}} \mathrm{E}_{\mathrm{H}}-\mathrm{G}_{\mathrm{Y}}$ ) contained a large bacterial biomass (respectively, 8 and $5 \mathrm{~g}$ of $\mathrm{C} / \mathrm{kg}$ of $\mathrm{OM}$ ). However, the activity of the bacterial community in this material, expressed as incorporation of ${ }^{14} \mathrm{C}$-Leu, was low (Figure $3 \mathrm{~B})$. Feces produced on diets with a mature grass silage $\left(\mathrm{P}_{\mathrm{L}} \mathrm{E}_{\mathrm{L}}-\mathrm{G}_{\mathrm{O}}\right.$ and $\left.\mathrm{P}_{\mathrm{H}} \mathrm{E}_{\mathrm{L}}-\mathrm{G}_{\mathrm{O}}\right)$ showed the opposite and combined a relatively low microbial biomass with a high activity.

Correlations between fecal and microbial characteristics are presented in Table 3. Strong positive correlations between the bacterial biomass present and the concentration of $\mathrm{N}_{\text {inorg }}, \mathrm{N}_{\text {total }}$, and $\mathrm{N}_{\text {org }}$ were found (Table 3). Bacterial biomass decreased as the $\mathrm{C}: \mathrm{N}$ ratio $\left(\mathrm{C}: \mathrm{N}_{\text {total }}\right.$ and $\mathrm{C}: \mathrm{N}_{\text {org }}$ ) of the feces increased. Microbial biomass was not correlated $(P>0.05)$ with the DM and
$\mathrm{C}_{\text {total }}$ content of the feces. Bacterial activity was strongly positively correlated $(P=0.004)$ with the DM content of the feces and strongly negatively correlated $(P \leq 0.001)$ with the $\mathrm{C}_{\text {total }}$ content of the feces.

\section{Comparison Observed and Predicted Values}

Predicted values followed a similar trend as the observed values for the $\mathrm{N}$ concentration and the C: $\mathrm{N}_{\text {total }}$ ratio of the feces. However, the concentration of $\mathrm{N}$ in the feces was generally overestimated by the model (Figure 1A and 4). The root MSPE was $5.9 \mathrm{~g}$ of N/kg of OM, which was $23 \%$ of the observed mean fecal $\mathrm{N}$ concentration. The overestimation of the $\mathrm{N}$ concentrations is also seen in the predicted $\mathrm{C}: \mathrm{N}_{\text {total }}$ ratios, which were all lower than the observed values. The root MSPE was 4.4 , which was $24 \%$ of the observed mean C: $\mathrm{N}_{\text {total }}$ ratio for the feces.

The determined microbial biomass $\mathrm{C}$ was compared with the simulated amount of microbial biomass produced in the large intestine (Figure 3A and 4). Model estimates were higher than the observed values for all measurements. The root MSPE was $6.2 \mathrm{~g}$ of $\mathrm{C} / \mathrm{kg}$ of OM, which is about $157 \%$ of the observed mean microbial biomass $\mathrm{C}$.

The model for microbial biomass showed a linear bias (slope $=-0.60 \pm 0.27, P=0.04$ ). This implies a bias of 
A

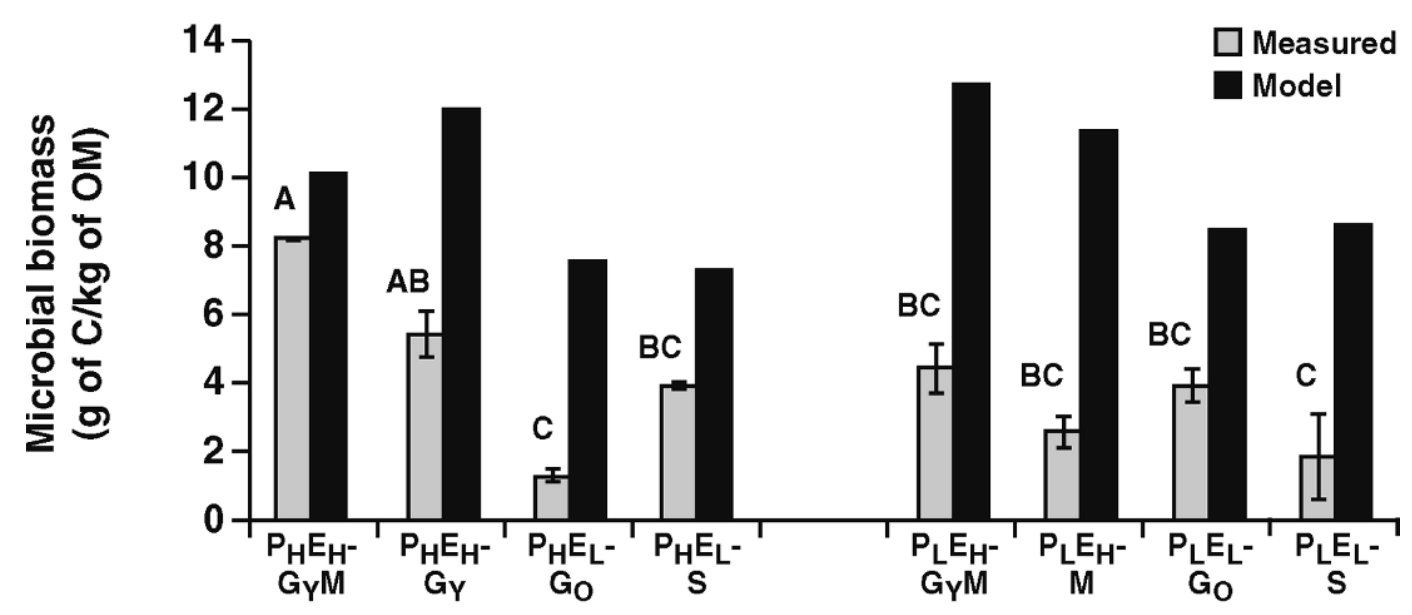

B

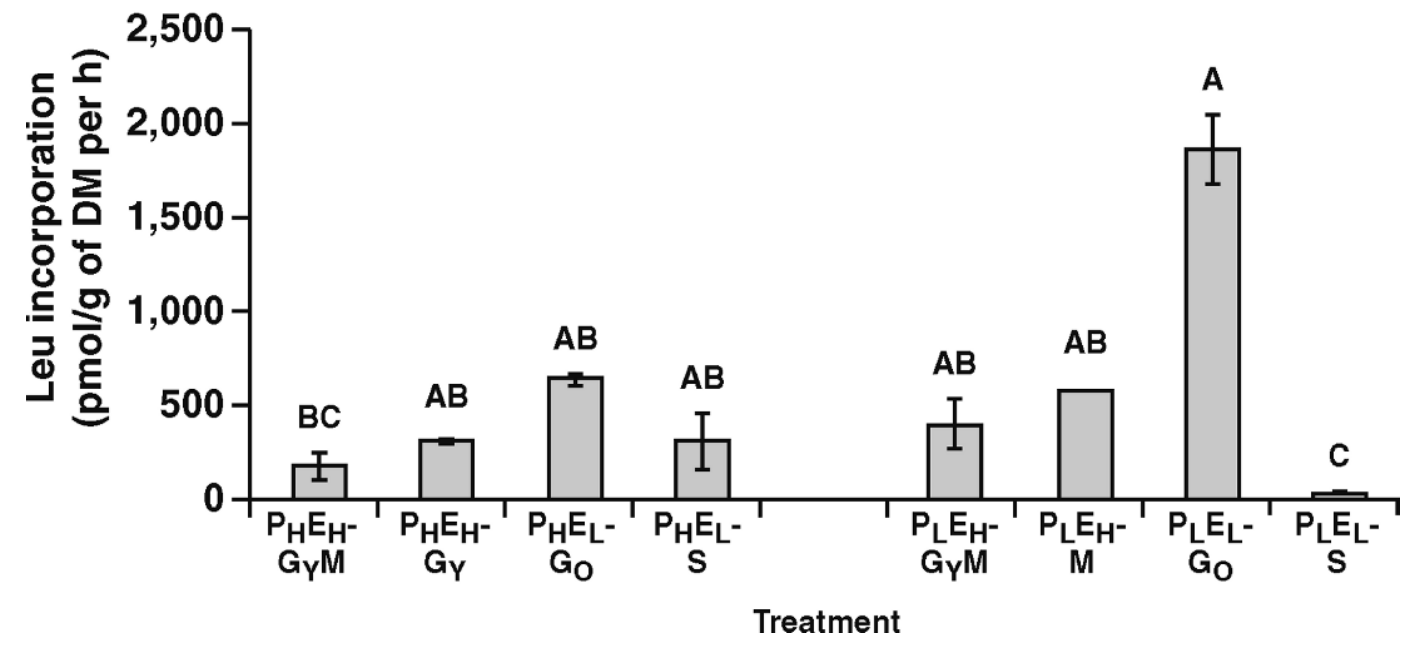

Figure 3. Microbiological characteristics of the feces of the different feeding regimens (average and standard error). A) Measured and predicted bacterial biomass in grams of C per kilogram of OM present in the feces; SEM (measured) $=0.55$. B) Growth rate of bacteria determined by ${ }^{14} \mathrm{C}$-Leu incorporation; SEM (measured) $=151.9 .{ }^{\mathrm{A}-\mathrm{C}}$ Letters in the graph denote significant differences between the measured data of the treatments $(P<0.05)$. $\mathrm{P}_{\mathrm{H}}=$ high protein; $\mathrm{P}_{\mathrm{L}}=$ low protein; $\mathrm{E}_{\mathrm{H}}=$ high energy; $\mathrm{E}_{\mathrm{L}}=$ low energy; $\mathrm{G}_{\mathrm{Y}}=$ young grass silage; $\mathrm{G}_{\mathrm{O}}=$ old grass silage; $\mathrm{M}=$ maize; $\mathrm{S}=$ straw. The numbers next to the codes refer to the different cows.

Table 3. Correlations between feces characteristics and bacterial biomass (total direct counts) and growth rate (Leu incorporation)

\begin{tabular}{|c|c|c|c|c|}
\hline \multirow{2}{*}{$\begin{array}{l}\text { Feces } \\
\text { characteristics }^{1}\end{array}$} & \multicolumn{2}{|c|}{$\begin{array}{l}\text { Microbial biomass } \\
(\mu \mathrm{g} \text { of } \mathrm{C} / \mathrm{g} \text { of } \mathrm{DM})\end{array}$} & \multicolumn{2}{|c|}{$\begin{array}{l}\text { Leu incorporation } \\
(\mathrm{pmol} / \mathrm{g} \text { of DM per } \mathrm{h})\end{array}$} \\
\hline & Pearson & $P$-value & Pearson & $P$-value \\
\hline $\mathrm{DM}(\%)$ & & NS & 0.696 & 0.004 \\
\hline $\mathrm{C}_{\text {total }}(\mathrm{g} / \mathrm{kg}$ of $\mathrm{DM})$ & & NS & -0.808 & $<0.001$ \\
\hline $\mathrm{C}: \mathrm{N}_{\text {org }}$ & -0.581 & 0.018 & & NS \\
\hline $\mathrm{C}: \mathrm{N}_{\text {total }}$ & -0.601 & 0.014 & & NS \\
\hline$N_{\text {inorg }}(g / k g$ of $D M)$ & 0.795 & 0.000 & & NS \\
\hline$N_{\text {org }}(\mathrm{g} / \mathrm{kg}$ of $\mathrm{DM})$ & 0.626 & 0.010 & & NS \\
\hline $\mathrm{N}_{\text {total }}(\mathrm{g} / \mathrm{kg}$ of $\mathrm{DM})$ & 0.648 & 0.007 & & NS \\
\hline
\end{tabular}

${ }^{1} \mathrm{C}_{\text {total }}=$ total $\mathrm{C}$ content of feces; $\mathrm{N}_{\text {org }}=$ organic $\mathrm{N} ; \mathrm{N}_{\text {total }}=$ total $\mathrm{N}$ content of feces; $\mathrm{N}_{\text {inorg }}=$ inorganic $\mathrm{N}$. less than $4.3 \mathrm{~g}$ of $\mathrm{C} / \mathrm{kg}$ of $\mathrm{OM}$ at the minimum $(7.3 \mathrm{~g}$ of $\mathrm{C} / \mathrm{kg}$ of OM) and of less than $7.6 \mathrm{~g}$ of $\mathrm{C} / \mathrm{kg}$ of OM at the maximum $(12.7 \mathrm{~g}$ of $\mathrm{C} / \mathrm{kg}$ of $\mathrm{OM})$ predicted microbial biomass $\mathrm{C}$. These biases are much larger than the standard error (0.55). In this model, the overall prediction bias or mean bias was also significant (intercept $=-5.79$ $\pm 0.53, P<0.001)$.

\section{DISCUSSION}

\section{Chemical Aspects}

The DM content of the feces of the nonlactating cows used in this experiment (average 15\%) was higher than the DM contents of dung pats from dairy cattle and 


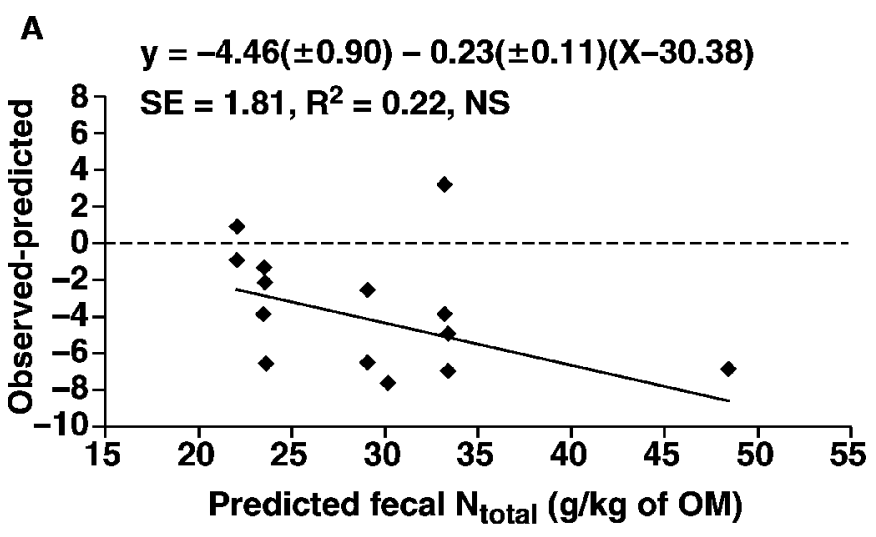

B $\quad y=3.63( \pm 0.61)+0.30( \pm 0.22)(X-14.63)$

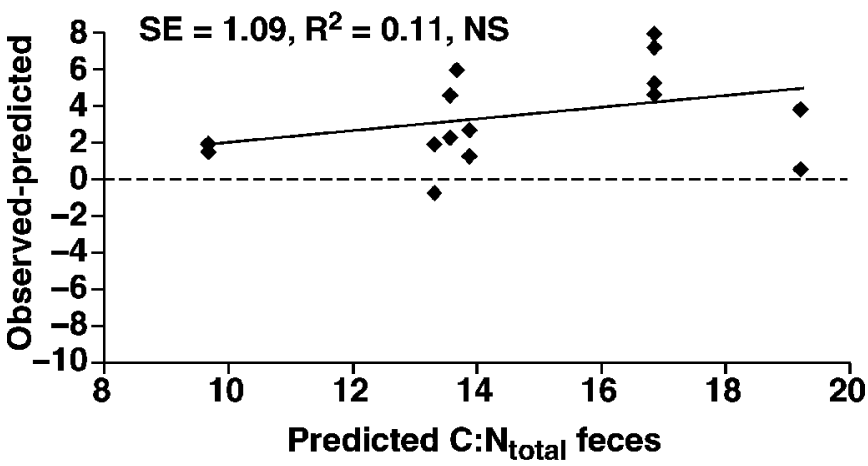

C $\quad y=-5.79( \pm 0.53)-0.60( \pm 0.27)(X-9.76)$

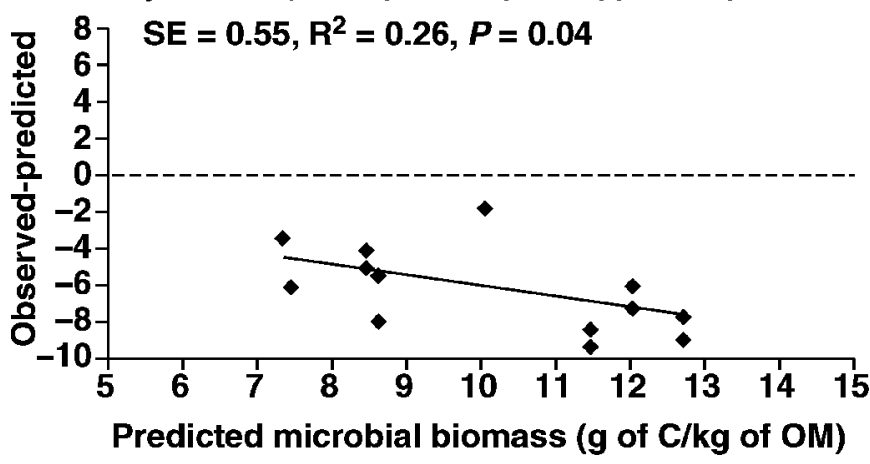

Figure 4. Residual vs. predicted values for fecal total $\mathrm{N}$ content of feces $\left(\mathrm{N}_{\text {total }}, \mathrm{A}\right), \mathrm{C}: \mathrm{N}_{\text {total }}(\mathrm{B})$, and microbial biomass $\mathrm{C}(\mathrm{C})$. The independent predicted variables were centered around the mean predicted values before the residuals were regressed on the predicted values. Standard error for the observed values and for the intercept and slope are shown in each plot.

young steers (range 10 to $14 \%$ ) collected by Bosker et al. (2002). Holter and Urban (1992) found slightly higher DM contents $[16.8 \pm 1.6 \%$ (average \pm SD)] for dry pregnant Holstein cows fed on different forages. The fraction of $\mathrm{N}_{\text {inorg }}$ in the feces (5 to $8 \%$ ) was larger compared with some other studies. Whitehead (1995) found 1.5 to $4 \%$, Oenema et al. (2000) found 1 to $4 \%$, whereas van der Meer (1991) found 7.5\% of $\mathrm{N}_{\text {inorg }}$ in feces of dairy cattle. After collection, the feces were kept at $4^{\circ} \mathrm{C}$, which should have prevented the release of mineral $\mathrm{N}$ out of easily decomposable $\mathrm{N}_{\text {org }}$ compounds present in the feces.

Similar to other studies (Kyvsgaard et al., 2000; Sørensen et al., 2003), we find that the concentration of $\mathrm{N}_{\text {org }}$ in the feces increases as the digestibility of the diet increases. The model provides insight into the mechanisms responsible for this increase. The higher DM intake level on the high-energy diets will increase fractional passage rates and consequently result in lower fractions of DM fermented in the rumen and a higher efficiency of microbial protein synthesis (Dijkstra et al., 2002). The higher simulated flow of OM (largely fiber) into the large intestine on high-energy diets will increase the endogenous protein losses, because these losses are related to the flow of indigested matter through the gastrointestinal tract (Tamminga et al., 1994). Moreover, a relatively higher fraction of the large intestinal flow of $\mathrm{OM}$ on the high-energy diets consists of potentially fermentable OM that has bypassed rumen fermentation and thus will increase microbial biomass production in the large intestine (Figure $3 \mathrm{~A}$ ).

Simulated and estimated bacterial biomass were qualitatively similar for the different diets; the highenergy $\left(E_{H}\right)$ rations always had a higher biomass than the low-energy $\left(\mathrm{E}_{\mathrm{L}}\right)$ rations. Bacterial biomass in the low-protein $\left(\mathrm{P}_{\mathrm{L}}\right)$ rations was high, because a reduced protein concentration in the feed coincides with a higher concentration of carbohydrates. Some of these carbohydrates will enter the large intestine and will be fermented in there. The low-protein rations also contained higher concentrations of starch. Starch that has bypassed the rumen and the small intestine is also a good substrate for bacteria in the large intestine.

Predictions from the model for $\mathrm{N}_{\text {total }}$ and the C: $\mathrm{N}_{\text {total }}$ ratio in the feces differed maximal $24 \%$ of the mean, whereas $\mathrm{N}_{\text {total }}$ was overestimated and C: $\mathrm{N}_{\text {total }}$ underestimated. The overestimation of the $\mathrm{N}$ content of the feces is caused by an underestimation of the apparent $\mathrm{N}$ digestion or an overestimation of the OM digestion. This might be caused by errors in the input of the model or by (individual) deviations from the intestinal digestion coefficients used in the model. The latter effect might be amplified in this experiment, because extreme feeding regimens were used, whereas the intestinal digestion coefficients in the model are estimated as the average of a large range of feeding regimens.

The $\mathrm{P}_{\mathrm{L}} \mathrm{E}_{\mathrm{L}}-\mathrm{G}_{\mathrm{O}}$ and the $\mathrm{P}_{\mathrm{L}} \mathrm{E}_{\mathrm{L}}-\mathrm{S}$ diets had a high NDF and $\mathrm{ADF}$ content and had smaller amounts of $\mathrm{N}$ in the feces than the $\mathrm{P}_{\mathrm{L}} \mathrm{E}_{\mathrm{H}}-\mathrm{M}$ and $\mathrm{P}_{\mathrm{L}} \mathrm{E}_{\mathrm{H}}-\mathrm{G}_{\mathrm{Y}} \mathrm{M}$ diets. This is mainly due to the protein source in the different diets. In the $\mathrm{P}_{\mathrm{L}} \mathrm{E}_{\mathrm{L}}-\mathrm{G}_{\mathrm{O}}$ and the $\mathrm{P}_{\mathrm{L}} \mathrm{E}_{\mathrm{L}}-\mathrm{S}$ diets, the protein is 
derived from soy, which is highly degradable, resulting in a small concentration of undigested feed $\mathrm{N}$ in the feces. Protein in the $\mathrm{P}_{\mathrm{L}} \mathrm{E}_{\mathrm{H}^{-}} \mathrm{M}$ and $\mathrm{P}_{\mathrm{L}} \mathrm{E}_{\mathrm{H}^{-}} \mathrm{G}_{\mathrm{Y}} \mathrm{M}$ diets is for a large part derived from roughage; the protein is therefore of a lower quality than when derived from soy and is arduous to decompose.

Due to high plant cell wall levels (high NDF), high levels of lignin within the cell walls, and the low $\mathrm{N}$ content in the $\mathrm{P}_{\mathrm{L}} \mathrm{E}_{\mathrm{L}}-\mathrm{S}$ feeding regimen, the nutritive value of this feeding regimen was low and resulted in feces with the highest $\mathrm{C}: \mathrm{N}_{\text {total }}$. The reduction in energy level in the high-protein feeding regimens $\left(\mathrm{P}_{\mathrm{H}} \mathrm{E}_{\mathrm{H}}-\mathrm{G}_{\mathrm{Y}} \mathrm{M}\right.$ $+\mathrm{P}_{\mathrm{H}} \mathrm{E}_{\mathrm{H}}-\mathrm{G}_{\mathrm{Y}}$ to $\mathrm{P}_{\mathrm{H}} \mathrm{E}_{\mathrm{L}}-\mathrm{S}+\mathrm{P}_{\mathrm{H}} \mathrm{E}_{\mathrm{L}}-\mathrm{G}_{\mathrm{O}}$ ) resulted in feces with a lower concentration of total and $\mathrm{N}_{\text {inorg. }}$. The lower rumen fermentable OM with the low-energy diets may have reduced microbial protein synthesis in the rumen. Because microbial protein digestion in the gut is not $100 \%$, this reduction therefore results in decreased fecal $\mathrm{N}$ of microbial origin.

\section{Microbiological Aspects}

The number of bacteria found in the feces [on average $39 \times 10^{9}$ cells $(\mathrm{g}$ of DM $) \approx 6 \times 10^{9}$ cells $/ \mathrm{mL}$ ] was comparable to the number found by direct counts for liquid swine manure $\left[1 \times 10^{10}\right.$ cells/mL by Leung and Topp (2001)] but lower than the number found by Cotta et al. (2003), who recorded $2 \times 10^{11}$ bacteria/g in fresh swine feces. The amount of microbial $\mathrm{C}$ in the feces is determined by microbial synthesis in the rumen and large intestine; the simulations indicated that the major part of microbial $\mathrm{C}$ in the feces is of rumen origin (undigested rumen microbial biomass). In the rumen, synthesis is mainly dependent on the availability of degradable energy and protein. Because the rumen fermentation of starch is usually higher than that of fiber, a lower starch content in the diet will provoke a lower amount of fermentable $\mathrm{ME}$ for microbial synthesis. In the large intestine, the synthesis is probably dependent on the amount of available carbohydrates (fiber and starch) not fermented in the rumen or digested in the small intestine. The amount of microbial $\mathrm{C}$ is also very much dependent on this flow. In our study, the percentage of microbial biomass $\mathrm{C}$ in the fresh feces varied from $0.3\left(\mathrm{P}_{\mathrm{H}} \mathrm{E}_{\mathrm{L}}-\mathrm{G}_{\mathrm{O}}\right)$ to $1.9 \%\left(\mathrm{P}_{\mathrm{H}} \mathrm{E}_{\mathrm{H}}-\mathrm{G}_{\mathrm{Y}} \mathrm{M}\right)$. In the model used in our study, microbially derived $\mathrm{C}$ in the feces ranged from 12 to $24 \%$ of the $\mathrm{C}_{\text {total }}$ present. However, statistical tests showed that the model is biased. The linear bias translates to values at the minimum and maximum level that are much larger than the standard error, implicating that the model does not simulate microbial biomass well. The differences between measured and predicted values are large and are probably due to a difference in definition of microbial $\mathrm{C}$. The microbial biomass $\mathrm{C}$ data in this study were calculated from the numbers of bacteria found in the feces. As stated earlier, the bacterial numbers recorded are comparable to other studies. For the conversion of numbers to microbial C, we have used the average cell volume based on the actual measured sizes of all individual cells and a specific $\mathrm{C}$ content of $310 \mathrm{fg}$ of $\mathrm{C} / \mu \mathrm{m}^{3}$ as proposed by Fry (1990). A potential error can be caused by the conversion of volume to mass. Therefore, we have calibrated our image analysis system using fluorescent microspheres of known sizes and by comparing bacterial biovolume with directly measured bacterial $\mathrm{C}$ (Bloem et al., 1995b). We assume that potential errors are similar for all fecal materials and that comparisons between diet treatments are valid. The prediction that 12 to $24 \%$ of the fecal $\mathrm{C}$ is microbially derived also includes damaged microbial material, whereas we have only recorded complete bacteria. Intact bacteria washed out from the rumen probably lyse in the acid abomasal environment, and subsequently, partial digestion of contents in damaged bacterial cells in the small intestine occurs. An indication of this partial digestion is the much lower digestion of diaminopimelic acid (a component of the bacterial cell wall) compared with that of AA and nucleic acids (Storm et al., 1983). These processes cause undigested material in the feces originating from rumen microbial matter from damaged microbial cells. This might explain the large difference between the 2 estimates. More measurements of microbial $\mathrm{C}$ in slurry manure, feces, or both, are needed to determine which estimate is closest to reality.

The bacterial diversity was higher than the diversity measured in manure slurry (van Vliet et al., 2006) and similar for all fecal materials. We assume that the number of bands on a DGGE-gel reflects the number of bacterial species. According to Hill et al. (2000), separation of DNA on the denaturant gradient will resolve individual bands, each corresponding to a unique sequence (genotype, presumably species). However, the relationship between bands on a fingerprint and the number of species present is not a simple 1-to-1 relationship. In a gram of manure, billions of bacteria are found, whereas the number of DNA bands on a gel is less than 100 . These are the abundant species. According to Zoetendal et al. (1998), DGGE is sensitive enough to detect bacteria that constitute as little as $1 \%$ of the total bacterial community present. Dilly et al. (2004) found an even lower detection limit of about $1 \%$. Differences in diet composition resulted in changes in the relative abundances of bacterial DNA bands (genotypes or species). These changes were induced mainly by the protein level of the diets. It is possible that a lowering of the protein level of the feed resulted in a shift within the bacterial community toward bacteria with a rela- 
tively high $\mathrm{N}$ assimilation efficiency. Because we have not identified the different bands on the DGGE gel, we cannot draw any conclusions about this possible shift. Kocherginskaya et al. (2001) determined bacterial diversity in rumen fluid of steers kept on a hay or corn diet with DGGE and a random sequencing approach. The species diversity was higher in the corn diet compared with the hay diet. On the contrary, we conclude that differences in diet composition did not affect the species composition of the feces but changed the relative abundances of the different species. Hypothesis 2 is rejected, because the species diversity of feces produced with low digestible feed $\left(\mathrm{P}_{\mathrm{H}} \mathrm{E}_{\mathrm{L}}-\mathrm{G}_{\mathrm{O}}, \mathrm{P}_{\mathrm{L}} \mathrm{E}_{\mathrm{L}}-\mathrm{G}_{\mathrm{O}}, \mathrm{P}_{\mathrm{H}} \mathrm{E}_{\mathrm{L}}-\mathrm{S}\right.$, and $\mathrm{P}_{\mathrm{L}} \mathrm{E}_{\mathrm{L}}-\mathrm{S}$ ) was not significantly statistically different from the species diversity of feces produced with other diets.

In the digestive tract of a cow, the fecal material endures anaerobic conditions. As soon as the material is voided from the body, feces are exposed to oxygen-rich conditions. The bacteria active in the digestive tract are obligately or facultatively anaerobic. The activity of obligately anaerobic bacteria in the feces will cease as soon as aerobic conditions occur, whereas facultative anaerobes will switch to aerobic metabolism (Paul and Clark, 1989). After exposure to lower temperatures outside the body and oxygen-enriched conditions, a large fraction of the bacterial biomass present in the feces will succumb. Dead cells may be incorporated in our total bacterial counts. The measured microbial biomass is therefore probably an overestimation of the living biomass present in the voided feces. No other measurements of microbial biomass in the feces are known, and for further evaluation of the model, more measurements need to be done.

The microbial activity measurements were not performed under anaerobic conditions. According to Michel and Bloem (1993), all bacteria can incorporate Leu. Feces of the $P_{H} E_{L}-G_{O}$ and $P_{L} E_{L}-G_{O}$ feeding regimens had the highest DM content and thus the lowest moisture content. This may have resulted in a fast aeration of the feces, resulting in a high activity of aerobic bacteria and therefore a high incorporation of Leu.

Microbial biomass in the feces was primarily affected by the composition of the feed supplied to the cow. The feces of the treatments $\mathrm{P}_{\mathrm{H}} \mathrm{E}_{\mathrm{H}^{-}} \mathrm{G}_{\mathrm{Y}}$ and $\mathrm{P}_{\mathrm{H}} \mathrm{E}_{\mathrm{H}^{-}} \mathrm{G}_{\mathrm{Y}} \mathrm{M}$ had a low $\mathrm{C}: \mathrm{N}_{\text {org }}$ ratio, a high microbial biomass, and a high $\mathrm{N}_{\text {inorg }}$ concentration. The $\mathrm{P}_{\mathrm{H}} \mathrm{E}_{\mathrm{H}}-\mathrm{G}_{\mathrm{Y}}$ diet (low C:N ratio, low NDF, see Table 1) contained a large amount of $\mathrm{N}$ and many easily decomposable $\mathrm{C}$ sources. A C:N ratio of 5 and an efficiency of 30\% are generally assumed for bacteria (de Ruiter et al., 1993). In that case, when the $\mathrm{C}: \mathrm{N}$ ratio of the organic material (feed) is lower than 15 , net mineralization of $\mathrm{N}$ occurs, whereas at a higher $\mathrm{C}: \mathrm{N}$ ratio, net immobilization of $\mathrm{N}$ by the microorgan- isms occurs (Bloem et al., 1997). This $\mathrm{N}$ is fixed in microbial biomass. After passage through the rumen, C limitation has probably occurred in the large intestine, and the microbial community present in the intestine became less active. When bacterial production rates are limited, for instance, due to a limited $\mathrm{C}$ supply, and a relatively large amount of $\mathrm{N}$ is present, part of the protein will not be used for production of bacterial biomass but will be mineralized. This can result in higher $\mathrm{N}_{\text {inorg }}$ concentrations in the fecal material. The $\mathrm{P}_{\mathrm{H}} \mathrm{E}_{\mathrm{H}}-\mathrm{G}_{\mathrm{Y}} \mathrm{M}$ regimen had an even lower NDF value, which resulted in a similar scenario as the $\mathrm{P}_{\mathrm{H}} \mathrm{E}_{\mathrm{H}}-\mathrm{G}_{\mathrm{Y}}$ treatment: low $\mathrm{C}: \mathrm{N}_{\text {org }}$ ratio, high bacterial numbers, and high $\mathrm{N}_{\text {inorg }}$ concentration in the feces. The highest $\mathrm{N}_{\text {inorg }}$ content was measured in the feces of this diet. In the feeding regimens with a high $\mathrm{CP}$ and high energy level, a potentially large amount of fermentable material will arrive in the hindgut, resulting in $\mathrm{N}_{\text {org }}$ concentrations in the feces that were higher than any of the other feeding regimens. However, these concentrations remain small when compared with the $\mathrm{N}$ concentrations excreted in urine.

Overall, bacterial biomass in the feces reflected the feeding regimen. Diets with low protein and high fiber content resulted in less bacterial biomass and less excretion of $\mathrm{N}$ in the feces. Although the absolute amount of excreted $\mathrm{N}$ was clearly reduced in these diets (less in, less out), the fraction of $\mathrm{N}_{\text {inorg }}$ in the feces and thus immobilization into bacterial biomass was not significantly different compared with the other feeding regimens.

\section{Consequences}

In practical farming situations, feces are combined with urine into slurry manure. Urine contains a high concentration of $\mathrm{N}$. The $\mathrm{C}: \mathrm{N}$ ratio of the slurry manure will therefore be much lower than that of the feces. In this experiment, the $\mathrm{C}: \mathrm{N}$ ratio of the slurry manure ranged from $5\left(\mathrm{P}_{\mathrm{H}} \mathrm{E}_{\mathrm{H}^{-}} \mathrm{G}_{\mathrm{Y}}\right)$ to $11\left(\mathrm{P}_{\mathrm{L}} \mathrm{E}_{\mathrm{L}}-\mathrm{G}_{\mathrm{O}}\right)$. Reijs et al. (2007) used these slurries in a field experiment and found a negative relationship between the C:N ratio of the slurries and the $\mathrm{N}$ availability in the soil. A reduction of the dietary protein content of the feed resulted in a significant decrease of the first-year $\mathrm{N}$ availability. However, the addition of manures with a high C:N ratio may contribute to the soil $\mathrm{N}$ supply in the longer run, as was shown in a long-term experiment by Silgram and Chambers (2002). In their experiment, $10 \mathrm{yr}$ of addition of straw increased the size of the labile soil $\mathrm{N}_{\text {org }}$ fraction, which contributed to the soil $\mathrm{N}$ supply. Simulations using the $\mathrm{P}_{\mathrm{L}} \mathrm{E}_{\mathrm{L}}-\mathrm{G}_{\mathrm{O}}$ and $\mathrm{P}_{\mathrm{H}} \mathrm{E}_{\mathrm{H}}-\mathrm{G}_{\mathrm{Y}}$ slurry manures showed that the usage of $\mathrm{P}_{\mathrm{L}} \mathrm{E}_{\mathrm{L}}-\mathrm{G}_{\mathrm{O}}$ slurry manure due to its high C:N ratio led to a reduced availabil- 
ity of $\mathrm{N}_{\text {inorg }}$ (Reijs et al., 2007). This has to be compensated by soil $\mathrm{N}$ mineralization, which in turn is driven by $\mathrm{OM}$ input. The chemical composition, in particular the $\mathrm{DM}$ and $\mathrm{C}$ content of the feces, which is affected by diet composition, is therefore important.

The model used in this experiment was developed on a wide variety of diets, including a wide range of DMI levels and fractional passage rates. Extensive model evaluation did not indicate any relation between DMI level and prediction error. The model can therefore be used at low DMI levels (e.g., dry cattle) as well as high DMI levels (e.g., high-producing cattle). The manure composition of dry cows may differ from that of highproducing cattle, because fractional passage rates and digestibility will differ. However, this is no reason for model simulations to deviate from observations. Nonlactating dairy cows have very low requirements for energy and protein due to the absence of milk production. The low energy requirement made it possible to use forages with a very low digestibility (straw and low digestible grass silage) in this experiment. The low protein requirements implied a higher excretion of $\mathrm{N}$ in feces and urine compared with lactating cows with the same protein intake. Furthermore, it should be noted that only 2 cows per diet were used. This implies that differences between diets are heavily affected by feed intake, water intake, and digestion efficiency of the individual animals. Therefore, the relations between diet and feces characteristics observed in this experiment cannot be directly extrapolated to any other situation, especially not for lactating cows.

\section{CONCLUSIONS}

Currently, animal manure is valued as a source of essential plant nutrients and as a means to improve soil quality. One way of improving animal slurry quality is adoption of a different feeding strategy. This study showed that diets with low protein and high fiber content resulted in less bacterial biomass and less excretion of $\mathrm{N}$ in the feces. However, the fraction of $\mathrm{N}_{\text {inorg }}$ in the feces and thus immobilization into bacterial biomass or organic metabolites was not significantly different (hypothesis 1 rejected). The low-protein, high-fiber feeding regimens did not result in higher species diversity of the bacterial communities present in the manure (hypothesis 2 rejected) but did result in a shift in relative abundance of certain bacteria induced by the protein level of the feeding regimen. Thus, the bacterial community structure was changed, but the bacterial $\mathrm{N}$ assimilation efficiency was not increased. The mechanistic model that simulates manure and feces composition with feed composition as intake was satisfactory for the chemical constituents of the feces $\left(\mathrm{N}_{\text {total }}\right.$ and
$\left.\mathrm{C}: \mathrm{N}_{\text {total }}\right)$ and assisted in understanding of the variations in feces composition induced by dietary changes. However, simulated and observed microbial biomass $\mathrm{C}$ differed to a significant extent (hypothesis 3 partly accepted and partly rejected).

\section{ACKNOWLEDGMENTS}

We thank An Vos, Popko Bolhuis, Meint Veninga, and Bert van der Stelt (Wageningen University and Research Center) for their assistance with the laboratory work. We also like to thank 2 anonymous reviewers for their comments on an earlier version of the manuscript. This study was funded by a grant from the Foundation for Soil Knowledge Development and Transfer and Wageningen University and Research Centre.

\section{REFERENCES}

Atlas, R. M., and R. Bartha. 1987. Microbial Ecology. Fundamentals and Applications. 2nd ed. Benjamin/Cummings Publ. Co. Inc., Menlo Park, CA.

Bloem, J., and P. R. Bolhuis. 2006. Thymidine and leucine incorporation to assess bacterial growth rate. Pages 142-149 in Microbiological Methods for Assessing Soil Quality. J. Bloem, A. Benedetti, and D. W. Hopkins, ed. CABI, Wallingford, UK.

Bloem, J., P. R. Bolhuis, M. R. Veninga, and J. Wieringa. 1995a. Microscopic methods for counting bacteria and fungi in soil. Pages 162-173 in Methods in Applied Soil Microbiology and Biochemistry. K. Alef and P. Nannipieri, ed. Acad. Press, London, UK.

Bloem, J., P. C. de Ruiter, and L. A. Bouwman. 1997. Food webs and nutrient cycling in agro-ecosystems. Pages 245-278. in Modern Soil Microbiology. J. D. van Elsas, J. T. Trevors, and E. Wellington, ed. Marcel Dekker Inc., New York, NY.

Bloem, J., M. Veninga, and J. Shepherd. 1995b. Fully automated determination of soil bacterium numbers, cell volumes and frequencies of dividing cells by confocal laser scanning microscopy and image analysis. Appl. Environ. Microbiol. 61:926-936.

Børsting, C. F., T. Kristensen, L. Misciattelli, T. Hvelplund, and M. R. Weisbjerg. 2003. Reducing nitrogen surplus from dairy farms. Effects of feeding and management. Livest. Prod. Sci. 83:165-178.

Bosker, T., T. Hoekstra, and E. A. Lantinga. 2002. The influence of feeding strategy on growth and rejection of herbage around dung pats and their decomposition. J. Agric. Sci. 139:213-221.

Castillo, A. R., E. Kebreab, D. E. Beever, and J. France. 2000. A review of efficiency of nitrogen utilization in lactating dairy cows and its relationship with environmental pollution. J. Anim. Feed Sci. 9:1-32.

Cotta, M. A., T. R. Whitehead, and R. L. Zeltwanger. 2003. Isolation, characterization and comparison of bacteria from swine faeces and manure storage pits. Environ. Microbiol. 5:737-745.

de Ruiter, P. C., J. C. Moore, K. B. Zwart, L. A. Bouwman, J. Hassink, J. Bloem, J. A. D. Vos, J. C. Y. Marinissen, W. A. M. Didden, G. Lebbink, and L. Brussaard. 1993. Simulation of nitrogen mineralization in the below-ground food webs of two winter wheat fields. J. Appl. Ecol. 30:95-106.

Dijkstra, J., E. Kebreab, J. A. N. Mills, W. F. Pellikaan, S. López, A. Bannink, and J. France. 2007. Predicting the profile of nutrients available for absorption: From nutrient requirement to animal response and environmental impact. Animal 1:99-111.

Dijkstra, J., J. A. N. Mills, and J. France. 2002. The role of dynamic modelling in understanding the microbial contribution to rumen function. Nutr. Res. Rev. 15:67-90.

Dilly, O., J. Bloem, A. Vos, and J. C. Munch. 2004. Bacterial diversity in agricultural soils during litter decomposition. Appl. Environ. Microbiol. 70:468-474. 
Dolfing, J., A. Vos, J. Bloem, N. N. Naumova, and P. J. Kuikman. 2004. Bacterial diversity in archived agricultural soils. Science 306:813.

Fry, J. C. 1990. Direct methods and biomass estimation. Pages 4185 in Methods in Microbiology. Vol. 22. Techniques in Microbial Ecology. R. Grigorova and J. R. Norris, ed. Acad. Press, London, UK.

Hill, G. T., N. A. Mitkowski, L. Aldrich-Wolfe, L. R. Emele, D. D. Jurkonie, A. Ficke, S. Maldonado-Ramirez, S. T. Lynch, and E. B. Nelson. 2000. Methods for assessing the composition and diversity of soil microbial communities. Appl. Soil Ecol. 15:25-36.

Holter, J. B. and W. E. Urban, Jr. 1992. Water partitioning and intake prediction in dry and lactating Holstein cows. J. Dairy Sci. 75:1472-1479.

Houba, V. J. G., J. J. van der Lee, and I. Novozamsky. 1997. Soil Analysis Procedures. Other Procedures (Soil and Plant Analysis, Part 5B). Wageningen Univ., Wageningen, the Netherlands.

Janssen, B. H. 1996. Nitrogen mineralization in relation to C:N ratio and decomposability of organic materials. Plant Soil 181:39-45.

Kebreab, E., J. France, J. A. N. Mills, R. Allison, and J. Dijkstra. 2002. A dynamic model of $\mathrm{N}$ metabolism in the lactating dairy cow and an assessment of impact of $\mathrm{N}$ excretion on the environment. J. Anim. Sci. 80:248-259.

Kocherginskaya, S. A., R. I. Aminov, and B. A. White. 2001. Analysis of the rumen bacterial diversity under two different diet conditions using denaturing gradient gel electrophoresis, random sequencing, and statistical ecology approaches. Anaerobe 7:119134.

Kyvsgaard, P., P. Sørensen, E. Møller, and J. Magid. 2000. Nitrogen mineralization from sheep faeces can be predicted from the apparent digestibility of the feed. Nutr. Cycl. Agroecosyst. 57:207-214.

Leung, K., and E. Topp. 2001. Bacterial community dynamics in liquid swine manure during storage: Molecular analysis using DGGE/PCR of 16S rDNA. FEMS Microbiol. Ecol. 38:169-177.

Michel, P. H., and J. Bloem. 1993. Conversion factors for estimation of cell production rates of soil bacteria from $\left[{ }^{3} \mathrm{H}\right]$ thymidine and $\left[{ }^{3} \mathrm{H}\right]$ leucine incorporation. Soil Biol. Biochem. 25:943-950.

Muyzer, G., E. C. de Waal, and A. G. Uiterlinden. 1993. Profiling of complex microbial populations by denaturing gradient gel electrophoresis analysis of polymerase chain reaction-amplified genes coding for 16S rRNA. Appl. Environ. Microb. 59:695-700.

Muyzer, G., and K. Smalla. 1998. Application of denaturating gradient gel electrophoresis (DGGE) and temperature gradient gel electrophoresis (TGGE) in microbial ecology. Antonie Van Leeuwenhoek 73:127-141.

Oenema, O., G. L. Velthof, N. Verdoes, P. W. G. Groot Koerkamp, G. J. Monteny, A. Bannink, H. G. van der Meer, and K. W. van der Hoek. 2000. Forfaitaire waarden voor gasvormige stikstofverliezen uit stallen en mestopslagen. 107. Alterra, Wageningen, the Netherlands.

Ouwerkerk, D., and A. V. Klieve. 2001. Bacterial diversity within feedlot manure. Anaerobe 07:59-66.

Paul, E. A., and F. E. Clark. 1989. Soil microbiology and biochemistry. Acad. Press Inc., San Diego, CA.

Pell, A. N. 1997. Manure and microbes: Public and animal health problem. J. Dairy Sci. 80:2681-2773.

Reijs, J. W. 2007. Improving slurry by diet adjustments: A novelty to reduce $\mathrm{N}$ losses from grassland-based dairy farms. $\mathrm{PhD}$ Thesis. Wageningen Univ., Wageningen, the Netherlands.
Reijs, J. W., M. P. W. Sonneveld, P. Sørensen, R. L. M. Schils, J. C. J. Groot, and E. A. Lantinga. 2007. Effects of different diets on utilization of nitrogen from cattle slurry applied to grassland on a sandy soil in the Netherlands. Agric. Ecosyst. Environ. 118:65-79.

Silgram, M., and B. J. Chambers. 2002. Effects of long-term straw management and fertilizer nitrogen additions on soil nitrogen supply and crop yields at two sites in eastern England. J. Agric. Sci. 139:115-127.

Sørensen, P., M. R. Weisbjerg, and P. Lund. 2003. Dietary effects on the composition and plant utilization of nitrogen in dairy cattle manure. J. Agric. Sci. 141:79-91.

Sørensen, P., and E. S. Jensen. 1995. Mineralization-immobilization and plant-uptake of nitrogen as influenced by the spatial distribution of cattle slurry in soils of different texture. Plant Soil 173:283-291.

Stoddard, C. S., M. S. Coyne, and J. H. Grove. 1998. Fecal bacteria survival and infiltration through a shallow agricultural soil: Timing and tillage effects. J. Environ. Qual. 27:1516-1523.

Storm, E., D. S. Brown, and E. R. Orskov. 1983. The nutritive value of rumen micro-organisms in ruminants. 3 . The digestion of microbial and nucleic acids in, and losses of endogenous nitrogen from, the small intestine of sheep. Br. J. Nutr. 50:479-485.

St-Pierre, N. R. 2003. Reassessment of biases in predicted nitrogen flows to the duodenum by NRC 2001. J. Dairy Sci. 86:344-350.

Tamminga, S., W. M. van Straalen, A. P. J. Subnel, R. G. M. Meijer, A. Steg, C. J. G. Wever, and M. C. Blok. 1994. The Dutch protein evaluation system: The DVE/OEB-system. Livest. Prod. Sci. 40:139-155.

van Bruchem, J., and S. Tamminga. 1997. Sustainability and the future of animal production: Options for environmental tuning of the systems in the Netherlands for nitrogen, phosphorus and potassium. Pages 48-67 in Proc. 47th Annu. Meet. Can. Soc. Anim. Sci., Montreal, Quebec, Canada. McGill Univ., Montreal, Quebec, Canada.

van der Meer, H. 1991. Stikstofbenutting en -verliezen van gras en maisland: Stand van zaken in het onderzoek naar de stikstofproblematiek van gras- en maisland. 10. Agric. Res. Dept., Wageningen, the Netherlands.

Van Soest, P. J., J. B. Robertson, and B. A. Lewis. 1991. Methods for dietary fibre, neutral detergent fibre and non-starch polysaccharides in relation to animal nutrition. J. Dairy Sci. 74:35833597.

van Vliet, P. C. J., J. Bloem, and R. G. M. de Goede. 2006. Microbial diversity, nitrogen loss and grass production after addition of effective micro-organisms (EM) to slurry manure. Appl. Soil Ecol. 32:188-198.

Verhoeven, F. P. M., J. W. Reijs, and J. D. van der Ploeg. 2003. Rebalancing soil-plant-animal interactions: Towards reduction of nitrogen losses. NJAS. 51:147-164.

Whitehead, D. C. 1995. Grassland Nitrogen. CAB Int., Wallingford, UK.

Zoetendal, E. G., A. D. L. Akkermans, and W. M. Vos. 1998. Temperature gradient gel electrophoresis analysis from human fecal samples reveals stable and host-specific communities of active bacteria. Appl. Environ. Microbiol. 64:3854-3859.

Zoetendal, W. G., C. T. Collier, S. Koike, R. I. Mackie, and H. R. Gaskins. 2004. Molecular ecological analysis of the gastrointestinal microbiota: A review. J. Nutr. 134:465-472. 